\title{
Peran Komunikasi Dalam Mengelola Manajemen Stress (Studi Kasus: Universitas Budi Darma)
}

\author{
Anda Yanny, Ronda Deli Sianturi* \\ Program Studi Manajemen Ritel, Universitas Budi Darma, 20219, Indonesia. \\ Email: ${ }^{1}$ andayanny31@gmail.com, ${ }^{2}$ rondadeli398@gmail.com \\ Email Penulis Korespondensi: rondadeli398@gmail.com \\ Submitted: 13/08/2021; Accepted: 23/08/2021; Published: 30/08/2021
}

\begin{abstract}
Abstrak-Virus Covid-19 yang masuk ke Indonesia khususnya kota Medan, memaksa pemerintah menetapkan untuk meliburkan kegiatan pembelajaran secara tatap muka dan diganti dengan pembelajaran secara daring. Hal ini membuat beberapa mahasiswa mengalami kesulitan memahami pembelajaran yang diberikan dosen secara on line, begitu juga semester delapan yang melaksanakan bimbingan skripsi secara on line menggunakan beberapa aplikasi pembelajaran. Kesulitan ini membawa mahasiswa menuju stress, disamping mereka kurang memahami instruksi dosen ditambah lagi tekanan dari keluarga yang memaksa untuk secepatnya menyelesaikan skripsi mereka. Komunikasi adalah solusi dari permasalahan ini. Bentuk dan komunikasi yang baik akan mengurangi dampak stress bagi mahasiswa dan dapat memotivasi mereka untuk melalui pelaksanaan skripsi tanpa stress yang berat.
\end{abstract}

Kata Kunci: Komunikasi; Manajemen Stress

Abstract-The Covid-19 virus that entered Indonesia, especially the city of Medan, forced the government to cancel face-to-face learning activities and replace them with online learning. This makes some students have difficulty understanding the learning provided by the lecturer online, as well as the eighth semester who carries out online thesis guidance using several learning applications. This difficulty brings students to stress, besides they do not understand the lecturer's instructions plus pressure from their families who force them to finish their thesis as soon as possible. Communication is the solution to this problem. Good form and communication will reduce the impact of stress on students and can motivate them to go through the implementation of the thesis without heavy stress.

Keywords: Communication; Stress Management

\section{PENDAHULUAN}

Pendahuluan, Wabah Covid-19 yang melanda dunia memaksa semua kegiatan dilakukan tanpa harus berkumpul, begitu juga dengan Negara Indonesia yang membuat pemerintah menerbitkan surat edaran nomor 4 Tahun 2020 tanggal 24 Maret 2020 (Pusdiklat Pegawai Kementerian Pendidikan dan Kebudayaa, 2020) untuk melakukan pembelajaran dari rumah. Hal ini berimbas kepada seluruh mahasiswa khususnya semester delapan, dimana mereka akan mengerjakan skripsi.

Kota Medan merupakan kawasan Zona Merah yang ditetapakan oleh Pemerintah sebagai daerah tingkat tinggi penyebaran virus Corona itu sendiri (Tim detikcom - detikNews, 2020)sehingga berdasarkan keputusan pemerintahan Kota Medan mengharuskan kegiatan pembelajaran dilakukan dari rumah sampai dengan waktu yang tidak ditentuan.

Komunikasi Pengerjaan skripsi dilakukan melalui media on line, hal ini membuat mahasiswa sendiri kurang puas. Kegiatan bimbingan skripsi di Universitas Budi Darma dilakukan menggunakan aplikasi seperti Zoom Meeting, Google Meet, Google Classroom, What's app dan Gmail. Di Universitas Budi Darma sendiri kegiatan bimbingan skripsi ini merupakan tahun ke dua selama Covid-19 berlangsung.

Berdasarkan penelitan sebelumnya yang dilakukan oleh (Muslim, 2020) Moh. Muslim yang memperoleh kesimpulan bahwasannya Work Form Home (WHF) memiliki sisi positif dimana pada awalnya memaksa guru/dosen dan siswa/mahasiswa untuk melek internet akhirnya menjadikan ide ide kreatif yang produktif bermunculan dengan memanfaatkan media on line sehingga dapat menjadikan setiap orang berkarya dari rumah. Kemampuan ini menyesuaikan diri dan menikmati kondisi yang ada akan mengalihkan stress dari distress menjadi eustress.

Penelitian lain oleh Basthoumi Muslih yang membahas bahwasannya komunikasi terbukti memiliki dampak positif yang mampu meningkatkan motivasi seseorang,(Muslih, 2020) apalagi di masa covid-19 saat ini, dimana imunitas tubuh harus dijaga agar tidak mudah terserang penyakit. Salah satu cara menjaga imunitas tubuh, selain makan makanaan bersih, sehat dan bergizi adalah dengan berfikiran positif dan terus berkarya. Karena covid- 19 bukan halangan untuk maju meskipun segalanya dilakukan di dalam rumah.

Adapun penelitian yang dibuat ini memiliki tujuan untuk melihat apa dan bagaimana peranan komunikasi dalam mengelola manajemen stress di kalangan mahasiswa khususnya semester akhir saat akan menghadapi skripsi.

\section{METODE PENELITIAN}

\subsection{Metodeologi Penelitian}

Penelitian ini dilaksanakan di Universitas Budi Darma yang beralamat di jalan Sisingamangaraja No.338 Medan. Tahapan penelitian yang dilakukan adalah tahapan Pengumpulan Data. Dalam hal ini data yang dikumpulkan dalam bentuk tulisan tulisan dari berbagai artikel, dan buku yang membahas tentang komunikasi dan manajemen stress. Jumlah sample dalam dalam penelitian adalah lima orang seperti yang diuraikan Martah dan Kresno bahwasannya Penelitian kualitatif tidak 
mengenal adanya jumlah sampel minimum (sample size). Umumnya penelitian kualitatif menggunakan jumlah sampel kecil. Bahkan pada kasus tertentu menggunakan hanya satu informan saja. Setidaknya ada dua syarat yang harus dipenuhi dalam menentukan jumlah informan yaitu kecukupan dan kesesuaian (Ade Heryana, S.St, 2018)

\section{Metode Analisa Pemecahan Masalah}

Metode dalam menyelesaikan peneltian ini menggunakan metode deskriptif kualititatif Menurut Sugiyono dalam Evita (Evita, 2020) penelitian deskriptif adalah penelitian dengan metode untuk menggambarkan suatu hasil penelitian. Namun, hasil gambaran tersebut tidak digunakan untuk membuat kesimpulan yang lebih umum., bahwa penelitian ini punya tujuan untuk memberikan deskripsi, penjelasan, serta validasi suatu fenomena yang diteliti. Penjelasan, dan validasi tersebut akan diperoleh peneliti setelah mendeskripsikan karakteristik dari objek yang diteliti. Menurut Nazir dalam bukunya Metode penelitian (Moh Nazir, 2014) Metode deskrptif adalah satu metode dalam meneliti status kelompok manusia, suatu subjek, suatu set kondisi, suatu sistem pemikiran atau pun kelas peristiwa pada masa sekarang. Tujuan dari penelitian deskriptif ini adalah membuat deskripsi, gambaran atau lukisan secara sistematis serta hubungan antar fenomena yang diselidiki. Maka kesimpulan penelitian deskriptif kualitatif adalah Menurut Nana Syaodih Sukmadinata, penelitian deskriptif kualitatif ditujukan untuk mendeskripsikan dan menggambarkan fenomena-fenomena yang ada, baik bersifat alamiah maupun rekayasa manusia, yang lebih memperhatikan mengenai karakteristik, kualitas, keterkaitan antar kegiatan. Jenis penelitian deskriptif kualitatif menafsirkan dan menguraikan data yang ada bersamaan dengan situasi yang sedang terjadi (N. Syaodih, 2014)

\subsection{Komunikasi}

Everett M.Rogers seorang pakar sosiologi Pedesaan Amerika memberi pengertian bahwa komunikasi itu adalah proses dimana suatu ide dialihkan dari sumber kepada satu penerima atau lebih dengan maksud untuk mengubah tingkah laku mereka. Pengertian komunikasi lainnya diungkapkan oleh Shannon dan Weaver bahwa komunikasi adalah bentuk interaksi manusia yang saling pengaruh mempengaruhi satu sama lainnya, sengaja atau tidak disengaja. Tidak terbatas pada bentuk komunikasi menggunakan Bahasa Verbal, tetapi juga dalam hal ekspresi muka, lukisan, seni dan teknologi(Cangara Hafied, 2002)

Pada umumnya Jenis jenis komunikasi terdiri dari :(Budi KHO, 2019)

1. komunikasi verbal merupakan komunikasi dengan menggunakan kata kata yang diucapkan

2. Komunikasi non verbal merupakan komunikasi meliputi Bahasa tubuh, raut wajah

3. Komunikasi tertulis adalah proses penyampaian informasi dengan menggunakan berbagai tanda, simbol, gambar dan tipografi

Dalam buku Prof. Dr.Alo Liliweri, M.S (M. . Prof. Dr.Alo Liliweri, 2015) Alasan manusia berkomunikasi adalah

1. Untuk mempengaruhi orang lain

2. Membangun atau mempertahankan hubungan antarpersonal

3. Memperoleh berbagai pengetahuan

4. Membantu orang

5. Komunikasi untuk bermain

\subsection{Stress}

Stres adalah gangguan mental yang dihadapi seseorang akibat adanya tekanan. Tekanan ini muncul dari kegagalan individu dalam memenuhi kebutuhan atau keinginannya. Tekanan ini bisa berasal dari dalam diri, atau dari luar (Andriyani, 2019)

Stress adalah suatu tekanan/ketegangan yang dialami seseorang karena adanya ketidaksesuaian antara lingkungan dengan kapabilitas atau sumberdaya yang dimilikinya, sehingga menimbulkan reaksi reaksi terhadap kondisi-kondisi tersebut (M. P. Dr. Hj. Siti Patimah, 2016)

Katagori stress terbagi dua (Sukoco \& Bintang, 2018) Eustress (positif) dan Distress (negatif)

Eustres adalah Stres yang memiliki sisi positif eustress yang artinya pengalaman stres yang berlebihan, cukup untuk menggerakkan dan motivasi orang agar dapat mencapai tujuan, mengubah lingkungan mereka dan berhasil dalam menghadapi tantangan hidup. Sedangkan distress, merupakan derajat penyimpangan fisik, psikis dan prilaku dari fungsi yang sehat

\subsection{Manajemen Stress}

Manajemen stres adalah kemampuan penggunaan sumber daya (manusia) secara efektif untuk mengatasi gangguan atau kekacauan mental dan emosional yang muncul karena tanggapan (respon). Tujuan dari manajemen stres itu sendiri adalah untuk memperbaiki kualitas hidup individu itu agar menjadi lebih baik (Wikipedia, 2020).

\section{HASIL DAN PEMBAHASAN}

Hasil dari observasi wawancara kepada lima mahasiswa yang dijadikan sebagai informan dalam penelitian ini ditemukan bahwasannya informan pertama masih mendapatkan kesulitan memahami apa yang diarahkan oleh dosen pembimbing dalam skripsinya melaui aplikasi zoom meeting, dikarenakan sinyal di daerahnya kurang mendukung, stress menghadapi 
sinyal, maka informan tersebut akan belajar bersama teman temannya di salah satu tempat tinggal mereka secara bergiliran, yang tentunya hal ini kurang baik karena dikhawatirkan tidak mematuhi protokol kesehatan.

Informan ke dua merasa bimbingan skripsi dengan komunikasi melalui aplikasi what's app dan zoom meeting lebih menyenangkan karena tidak harus menghabiskan waktu ke kampus, dan menunggu dosen. Saat stress mencari jawaban atas pertanyaan dan koreksi dosen, maka Informan tersebut akan belajar ke perpustakaan kampus dengan mematuhi protokol kesehatan yang sudah ditetapkan kampus.

Informan ke tiga mengaku kurang puas bimbingan skripsi melalui aplikasi online, ditambah lagi Stress karena tekanan dari keluarga untuk segera menyelesaikan skripsi, maka untuk mengatasi stress mengerjakan skripsi tersebut, maka informan ke tiga akan berusaha belajar dari google dan video dari youtube.

Informan keempat proses bimbingan yang dilakukan melalui aplikasi on line terkadang membuatnya lupa apa yang diarahkan dosen pembimbing jika melalui aplikasi zoom, saat proses bimbingan berlagsung informan keempat malah tidak berani bertanya kepada dosen pembimbing, dikarenakan malu dan takut dianggap tidak paham oleh dosen pembimbing, terlebih tekanan rasa malu dengan teman temannya yang sudah lebih dahulu bergerak cepat dibandingkan dirinya. Stres menghadapi masalah tersebut, maka setiap bimbingan melalui aplikasi zoom, maka informan akan merekamnnya, Saat mulai mengerjakan skripsi informan keempat akan membuka kembali video rekaman tersebut.

Informan ke lima menganggap bimbingan melalui aplikasi on line sangatlah menyulitkannya memahami pengarahan yang diberikan oleh dosen pembimbing, ditambah lagi stress karena bolak balik minta uang kepada orang tuanya dikampung untuk membeli paket data internet, maka saat proses bimbingan on line, informan tersebut meminta bantuan temannya untuk ikut menyimak ulasan yang diberikan oleh dosen pembimbing baik melalui aplikasi chatting maupun zoom meeting, kemudian bersama sams mereka bahas.

\subsection{Pembahasan}

Stres yang dialami kelima informan tersebut dalam taraf sedang, dengan pola penyelesaian yang dilakukan berbeda beda, Hasil stres yang mereka alami malah meningkatkan motivasi mereka untuk mencari jalan keluar agar mereka dapat menyelesaikan skripsi. Hal ini sejalan dengan penelitian yang dilakukan Moh Muslim, dimana work from home ini akan memunculkan ide ide kreatif yang mengubah stress dari distress menjadi eustress atau stress yang positif. Terlihat ide ide kreatif yang mereka lakukan, mulai dari belajar berkelompok, belajar di perpustakaan, meminta bantuan teman, mengunduh video dari youtube maupun dari aplikasi zoom, ditengah stress yang menekan mereka, stress dari keluarga, stress mencari jawaban atas kritikan dosen, stress menghadapi sinyal sampai stress didahului teman

\section{KESIMPULAN}

Dari penelitian dapat disimpulkan bahwa peran komunikasi bimbingan yang dilakukan secara on line di Universitas Budi Darma mengakibatkan ketidak puasan mahasiswa dalam menangkap arahan yang diberikan oleh dosen pembimbing yang mengakibatkan stress yang terjadi pada mahasiswa malah mengakibatkan mereka mencari jalan untuk menyelesaikan skripsinya. Tekanan stress dari keluarga dan teman teman membuat mahasiswa termotivasi untuk berusaha menyelesaikan skripsi dengan memanafaatkan teknologi internet sebagai media komunikasi pembelajaran mereka. Manajemen Stress yang dikelola oleh mahasiswa dimasa pandemic Covid -19 menjadikan stress mereka positif.

\section{REFERENCES}

SURAT EDARAN MENDIKBUD NO 4 TAHUN 2020 TENTANG PELAKSANAAN KEBIJAKAN PENDIDIKAN DALAM MASA DARURAT PENYEBARAN CORONA VIRUS DISEASE (COVID-oel 1 9) (2020) https://pusdiklat.kemdikbud.go.id/, 2020.

Ade Heryana, S.St, M. K. (2018). Informan dan Pemilihan Informan dalam Penelitian Kualitatif. Universitas Esa Unggul. https://www.researchgate.net/publication/329351816_Informan_dan_Pemilihan_Informan_dalam_Penelitian_Kualitatif

Andriyani, J. (2019). Strategi Coping Stres Dalam Mengatasi Problema Psikologis. At-Taujih : Bimbingan Dan Konseling Islam, 2(2), 37. https://doi.org/10.22373/taujih.v2i2.6527

Budi KHO. (2019). Jenis-jenis Komunikasi (Verbal, Non-Verbal dan Tertulis). Ilmu Manajemen Indiustr. lmumanajemenindustri.com/jenis-jenis-komunikasi-verbal-non-verbal-tertulis/

Cangara Hafied. (2002). Pengantar Ilmu Komunikasi (4th ed.). PT Rajagrafindo Persada.

Evita. (2020). Penelitian Deskriptif - Pengertian, Kriteria, Contoh,. Quipper Blog. https://www.quipper.com/

M. . Prof. Dr.Alo Liliweri. (2015). Komunikasi Antar-Personal (Pertama). Kencana Prenadamedia Group.

M. P. Dr. Hj. Siti Patimah. (2016). MANAJEMEN STRES Perspektif Pendidikan Islam (kesatu). Anggota Ikatan Penerbit Indonesia (IKAPI).

Moh Nazir. (2014). . Metode Penelitian. Ghalia Indonesia.

Muslih, B. (2020). Urgensi Komunikasi dalam Menumbuhkan Motivasi di Era Pandemi Covid-19. Jurnal Penelitian Manajemen Terapan (PENATARAN), 5(1), 57-65.

Muslim, M. (2020). Moh . Muslim : Manajemen Stress pada Masa Pandemi Covid-19” 193. Jurnal Manajemen Bisnis, 23(2), 192201.

https://www.bing.com/search?q=jurnal+tentang+kebersihan+diri+sendiri+pada+masa+pandemi+remaja\&qs=n\&form=QBRE\& $\mathrm{sp}=-1 \& \mathrm{pq}=$ jurnal+tentang+kebersihan+diri+sendiri+pada+masa+pandemi $\& \mathrm{sc}=0$ -

56\&sk=\&cvid=F9158713DF0B4E9FAC0BC0C89C267AC0

N. Syaodih. (2014). "Penelitian Deskriptif Kualitatif. Tripven. 
Ekonomi, Keuangan, Investasi dan Syariah (EKUITAS)

Vol 3, No 1, Agustus 2021, Hal 17-20

ISSN 2685-869X (media online)

DOI 10.47065/ekuitas.v3i1.1022

Pusdiklat Pegawai Kementerian Pendidikan dan Kebudayaa. (2020). SURAT EDARAN MENDIKBUD NO 4 TAHUN 2020 TENTANG PELAKSANAAN KEBIJAKAN PENDIDIKAN DALAM MASA DARURAT PENYEBARAN CORONA VIRUS DISEASE (COVID$19)$. https://pusdiklat.kemdikbud.go.id/, 2020. .

Sukoco, I., \& Bintang, M. R. (2018). ANALISIS MANAJEMEN STRESS PADA PERUSAHAAN PERS (Studi pada PJTV). AdBispreneur, 2(3), 263. https://doi.org/10.24198/adbispreneur.v2i3.16494

Tim detikcom - detikNews. (2020). Medan Jadi Satu-satunya Zona Merah Corona di Sumut. Https://Pusdiklat.Kemdikbud.Go.Id/News.Detik.Com.

Wikipedia. (2020). Manajemen stres. Wikipedia. https://id.wikipedia.org. 